\section{B A Institute of \\ YK Business Administration \\ TK \\ Karachi \\ Leadership and Ideas for Tomorrow}

Business Review

Volume 4 Issue 2 July-December 2009

7-1-2009

\title{
The development of informal sector Small and Medium scale Enterprises through formation of cluster and networking: A case study based on Sri Lanka and Pakistan
}

\author{
S.W.S.B. Dasanayaka \\ University of Moratuwa, Moratuwa, Sri Lanka
}

Follow this and additional works at: https://ir.iba.edu.pk/businessreview

Part of the Entrepreneurial and Small Business Operations Commons, Growth and Development Commons, and the International Economics Commons

\section{(c) (;)}

This work is licensed under a Creative Commons Attribution 4.0 International License.

\section{Recommended Citation}

Dasanayaka, S. (2009). The development of informal sector Small and Medium scale Enterprises through formation of cluster and networking: A case study based on Sri Lanka and Pakistan. Business Review, 4(2), 107-122. Retrieved from https://doi.org/10.54784/1990-6587.1335

This article is brought to you by iRepository for open access under the Creative Commons Attribution 4.0 License and is available at https://ir.iba.edu.pk/businessreview/vol4/iss2/9. For more information, please contact irepository@iba.edu.pk. 


\title{
Case Study
}

\section{The Development of Informal Sector Small and Medium Scale Enterprises through Formation of Cluster and Networking. A Case Study based on Sri Lanka and Pakistan}

\author{
S.W.S.B. Dasanayaka \\ University of Moratuwa, Moratuwa, Sri Lanka
}

\begin{abstract}
The concepts of cluster and networking emerged in 1960s in Small and Medium Scale Enterprises (SMEs) literature but the formation of SME clusters and networking is a very new strategy for Sri Lanka started in 2001 and Pakistan started in 2003. But it shows some positive sign of growth by increasing competitiveness of SMEs by opening-up new opportunities due to good innovative networking, common facility usage and collective efficiency of economies of scale, scopes and synergies, etc. The problem of many SMEs in both countries is not their size, but being isolated and working in enclave nature, therefore SMEs individually have little capacity to respond to competitive pressure and to generate factors for expansion and innovation. Especially, SME Apex bodies and Authorities see the formation of clusters and networking as the way to reduce transaction cost of facility provision by creating new form of co-operation for sharing resources, information, technical expertise and knowledge, etc. But in turn, this can strengthen the competitiveness as well as facilitating learning and technical innovation and ultimately it helps SMEs to mobilize human, financial and other resources to one place by opening avenue for long lasting networking. Many successful empirical stories available regarding the effectiveness of SME cluster and networking formation around the world but Sri Lankan and Pakistan cases may be too early to judge the exact relationship between SME's success and cluster and networking formation as they recently started these concepts. But available evidences in some clusters and networking in both countries show that due to this SMEs growth and competitiveness have been increasing during the last few years in terms of various indicators. Therefore, this paper ascertains the implications of cluster and networking formation on growth and competitiveness of Sri Lankan and Pakistan's SMEs. This paper concludes by emphasizing that formation of clusters and promotion of networking is a very good start to develop and increase competiveness of SMEs but at the same time many other right policy initiatives, incentives, business development services and infrastructure facilities must be in place to better perform these clusters and networking relations to address SMEs complex and diverse problems. Especially, clusters and networking alone cannot be solved the complex problems and constraints encountered by SMEs in Sri Lanka and Pakistan to break the vicious cycle of SMEs.
\end{abstract}

Key words: Clusters, Networks, Small and Medium Scale Enterprises: SMEs, Sri Lanka, Pakistan. JEL Classification: O32, L2 


\section{INTRODUCTION}

The South-Asian region traditionally has been the cradle of small scale enterprises. There is evidence that right through ancient times, traders from the present day political entities of Pakistan and Sri Lanka have taken the produce and the manufactured goods to far away destinations. Even in recent recorded history certain areas in this region have excelled in specific items. Gems and ivory from Colombo (Sri Lanka) and surgical and sports goods from Sialkot (Pakistan) have created their impact of quality and customer acceptance all over the world. As the competition grew, the small scale enterprises as a natural process came together to develop their strength through unity of purpose. This gave birth to first clusters. Clusters have several advantages. These include a high degree of networking which stimulates productivity, ability to diversify and to acquire the capacity to new products when the demand for existing products falls. Swann and Baptista (1998) in positive feedback model aptly sum up how the clustering phenomenon, felt through the entry of new firms and the growth of incumbent firms, leads to a positive feedback loop, which will induce further growth within the cluster. Researchers who have studied benefits of clusters include Cook 2002, Feldman and Francis 2005, Harrison 2007 and Glavan 2007. The policy makers are searching ways to create new clusters. With an even more globalized world and increased competition the appeal of clusters has become stronger and more urgent. Yet, the formation and the sustenance of the clusters has somehow remained a mystery. There has been a limited research carried out in this direction. No doubt it is a complex area and no figurative results can be highlighted to show as to how the development of industrial clusters has taken place. In this context, this paper attempts to seek answers to the following research questions.

Q1: How do industrial clusters get created?

Q2: What sustains the dynamism of successful industrial clusters?

Q3: Can a pattern of success be discerned in clusters?

Q4: Can Government policies play a role in creating viable clusters?

The author go about seeking answers to these questions by examining the experience of some of the prominent and successful clusters, their formation and sustenance in both countries. The study further investigates various initiatives, the role and the results thereof in development of clusters.

The findings have resulted in a wealth of information about the dynamics of the clusters. The analysis should help to identify conditions for the formation of clusters, their maintenance and their viability. The analysis should be particularly valuable to policy makers and provide a focus for further research on the subject. 


\section{ORIGIN AND THE EVOLUTION}

Darwin advanced concept of collaboration as a tactic adopted by species for survival in a complex and uncertain environment. The small scale sector in specified products similarly came together to face a hostile, complex and uncertain business environment. The origins of the clusters thus can be visualized in an attempt of coming together to share knowledge and to supplement efforts of each other to create a name and a brand, which otherwise would have been outside the capabilities of an SME.

The cluster concept basically originates as a tool of achieving competitive advantages. Competitive advantage involves managing the entire value system, encompassing the value chains of the firm, suppliers, channels and buyers. The strongest competitive advantages often emerge from clusters. Thus clusters are not an unknown phenomenon. Colombo and Sialkot have been known as cluster towns for many years. Many crafts and skills have stayed in families through inheritance. Historically, clusters have been found in a wide variety of traditional industries (textiles in northern Italy, shipbuilding in Glasgow, steel in Pittsburgh, car manufacture in Detroit). In the British context, the clustering phenomenon was observed in the industrial revolution (cotton industry) and in earlier economies, for example, textiles in northern England and a financial cluster in the City of London (Kuah, 2002). Researchers attribute origins of modern day clusters to the decline of manufacturing industries in the states of Illinois, Indiana, Michigan, Ohio, and Pennsylvania and the decision of the entrepreneurs to seek new places with lower wages (Yusuf, 2008).

Collaborative linkages and networks, as an important strategy for the development of small business sector, are increasingly the focus of attention for entrepreneurs/managers, public policy makers and academics. This perspective of small enterprise linkages can be a particularly effective approach to overcome many of the traditional constraints facing small enterprises and to help in fostering the development of truly vibrant and economically viable small enterprises that can serve as a sustainable form of quality job creation and income generation for developing countries. Policy makers aim to increase the competitiveness by embedding of SMEs in horizontal linkages between firms (through clusters and networks) and vertical linkages with markets (through local and global value chains). While SMEs face difficulties in actively engaging in corporations, enterprise networks and clusters offer an adequate framework for responding to the increasingly demanding requirements from industry. By joining forces, both horizontally and vertically, and learning from other partners from the supply chain, SMEs are put in a much better position to compete.

Enterprise corporations offer small enterprises the opportunity to draw upon resources which enable them to collectively master more complex challenges. However, SMEs are slow to seek such solutions and only rarely engage in an active search for partners. Moreover, the importance of enterprise networks is increasing in terms of 
facilitating enterprise access to resources such as technology, qualification, information on market requirements, and business support services. Thus, clusters and networks are important tools for SMEs to enhance their access to technology and other resources and services which help them to stay competitive in a more globalized economy. The evolution and the growth of clusters can be thus visualized as a natural process which may not require policy regulatory policy.

\section{DEFINITIONS AND CLASSIFICATION OF CLUSTERS}

Porter (1990) introduces the concept of clusters as "groups of interconnected firms, suppliers, related industries and specialized institutions in particular fields that are present in particular locations".

Marshall (1890), characterized 'concentration of specialized industries in particular localities' that he termed as industrial districts. This local concentration of specialized activities exhibited external economies in the ready availability of skilled labour; the growth of supporting and ancillary trade; and the specialization of firms in different stages and branches of production. By being located close to one other, potential customers can reduce their searching costs and compare prices with quality. Reputation of a cluster in its quality or innovation will further draw customers to the location for their custom (Kuah,2002). In a broader context, as used in case of Sri Lanka in this paper, Cortright (2006) observes, that clusters represent a fundamental organizing framework for understanding regional economies and for developing economic strategies.

Clusters have been classified differently by researchers depending upon the needs and purposes of typology. Classification on the basis of number of units, strength of employment, turn-over, revenue generation, volume of exports usually find favour with policy makers and the regulators. Others have suggested classification as competitive, strategic, emerging, potential, and mature for the same users. Specific product, parts or the manufacturing process or supplies to a sector of industry is appropriate basis for commerce. Sarcina (2009) reports that research studies on role of SME clusters in organizational learning and the inter-relationship of various levels of learning has resulted in five main cluster types identified as Proterian, Segmented Proterian, Interlocking, Induced Partnership, and Virtual Cluster. For a study of the type as in this paper a more appropriate classification has been advanced by Markusen (1994), as:.

(a) Marshallian: Locally owned firms with substantial interfirm trade and collaboration, and strong institutional support

(b) Hub and Spoke: One or several large firms with numerous smaller supplier and service firms with cooperation between large firms and smaller suppliers on terms of the large( hub) firms

(c) Satellite platform: Theses comprise of medium-size and large branch plants with minimum inter-firm trade and networking 
(d) State anchored: Large public or non-profit entity related supplier and service firms, restricted to purchase-sale relationships between public entity and suppliers

\section{SME CLUSTERS: PAKISTAN EXPERIENCE}

SMEs constitute nearly 90 percent of all the enterprises in Pakistan, employ eighty of its non-agricultural work force and share 40 percent of GDP. (). SME policy interest explicitly started in 1998 with setting up of the Small and Medium Enterprises Development Authority (SMEDA). In 2001, UNIDO established an Industrial Information Network - INN, to promote SMEs in Pakistan and oversees, and facilitate entrepreneurs in e-commerce trade. UNIDO has developed SME clusters, in partnership with several trade associations. UNIDO is also providing a platform for the development of IT- SME clusters, through bringing in contributions from overseas Pakistanis and building partnerships with the media.

\section{Marble Processing cluster}

Marble and Granite is the sixth largest mineral extracted in Pakistan. Planning of the new capital city of Islamabad attracted this industry in a large way when two firms one each in Islamabad and close by Rawalpindi started their operations as processors. The stone mainly sourced from the province of NWFP in the shape of potato (as blasted), was processed as slabs and tiles, and sent to various cities all over the country. Number of units increased manifolds.

According to the industry estimates 1.37 million tons of marble and granite are produced annually; $97 \%$ of the same is consumed locally (SMEDA, 2006). Known reserves of marble and granite are 160 million tones and 2 billion tones respectively. Marble reserves are mostly concentrated in NWFP and Balochistan. Thar has granite reserves of 1.15 billion tones. Quarry operations in Pakistan lack latest technology. Stone is quarried randomly using simple drilling and dynamite splitting techniques. Explosives are used irrationally, creating major waste and poor quality rough blocks. About 50 percent of the material is wasted at the quarry and another 30 percent during fabrication. The irregular blocks produced are difficult to handle and create problems in lifting, transportation, storage, and fabrication. There exist very few units with complete range of machinery and equipment capable of processing stone in accordance with international standards. Out of over 1000 units, there are only about 25-30 units which claim to have latest technology and machinery to carry out operations of cutting and polishing of slabs.

\section{Gems \& Jewellery Clusters at Lahore and Karachi}

Pakistan is the fifth largest country for the occurrence of gemstones in the 
World. The country has been gifted with abundant resources of several precious and semi-precious gemstones, mostly quarried in the Northern provinces presently, but with large unexplored reserves in Balochistan. Precious stones found so far include emeralds (Swat), pink and golden topaz ( Mardan) and aquamarine in Chitral and Neelam Valley. Lahore and Karachi are the major hubs. Besides, the trade flourishes in more than thirty major towns and nearly three hundred smaller towns. In addition, in over 45,000 villages jewelers and makers of gold and silver ornaments operate as single-shops. Pakistan exports gems \& jewellery worth of US $\$ 32$ million per annum. This volume is insignificant in the total global trade of $\$ 84.4$ billion.

There is no formal survey carried out so far to identify the geological resources of gemstones in the country. The first gemstone mine in Pakistan was discovered in 1951, in the Haramosh Range. It took 27 years for the establishment of Gemstones Corporation of Pakistan (GEMCP). Within 15 years of its establishment, GEMCP was disbanded in 1993-94 and private sector was encouraged to invest in the sector. In 2007, the government formed Pakistan Gems \& Jewellery Development Company (PGJDC), a non-profit public/private entity for the development of the sector.

\section{Faisalabad Cotton Ginning Mills Cluster}

After separation from India in 1947, the cotton ginning industry had a desolate look due to the migration of Hindus and Sikh owners who largely possessed the technical and management know how. The new owners came to acquire the industry mostly by allotment as evacuee property and tried to operate the factories as best as could be possible. This practice continued from 1947 to 1950. In 1960, the cotton ginning factories were transferred from the allottees to the buyers. The new owners braved the situation and recorded success which proved catalytic for mushrooming of ginning mills in and around Faisalabad which form the cotton growing areas of Pakistan.

Faisalabad Textiles Cluster: Faisalabad being the major city in cotton growing areas houses weaving mills. It has around 50,000 weaving units with more than 400,000 weaving looms of different types. Even though the technology used is old, the sector has been able to create a mark in world markets because of innovatory designs in textiles and the low costs of production.

\section{The Case of Auto Parts SMEs}

The automotive assembling in Pakistan was pioneered in 1950 with setting up of National Motors Limited, a public limited company. Established by General Motors of USA, National Motors assembled well known brands of passenger cars as well as commercial vehicles. A regular car industry started in 1983, when Suzuki commenced production of the small and LCV car segment of $800 \mathrm{cc}-1000 \mathrm{cc}$ range, introducing Suzuki car which targeted the middle-income group. Indus Motor Company was established 
in early 90's to manufacture Toyota vehicles. Soon after, Honda Atlas started with Civic. Gandhara Nissan entered the market with Sunny. Later Dewan Motors set up a plant to manufacture Hyundai and Kia vehicles. The industry operates under franchise and technical cooperation agreements with Japanese, European and Korean manufacturers. Through indigenous technical resources and technical tie-ups with well-known global companies, the auto parts industry is well developed. Almost 400 units are registered as certified vendors to assemblers/OEMs. There are another 1200 units mostly catering to the replacement market.

\section{Sialkot Sports- goods Cluster}

Sialkot has been known world wide for its sports goods and accessories for more than 100 years. Its source of strength has been the right quality mulberry from the near by low hills of the Kashmir valley. Like Faisalabad, it wore a desolate look with the migration of Hindu/Sikh owners to India in 1947. However, soon the local skills and determination could establish and restart the business. Initially, the international buyers purchased sports goods from Sialkot and sourced sports wear from South Korea, Taiwan and other countries. Satisfied customers, however, asked the local manufacturers to produce sports wear as well. Now, contrary to world practices, the firms engaged in manufacturing of sportswear, are also producing sports goods. This has helped to leverage out risks into more than one product line. Export of these products amounted to $\$ 90$ million during 2004-05. The average growth rate for the past 3 years is 16 percent. However its share in international trade is a meager 4.5 percent. More than 10,000 skilled workmen are engaged in the cluster. Renowned brands as Addidas, Nike, Puma, and others source their requirements from the Sialkot cluster. Behind the success of Sialkot is the spirit of creativity and innovation of skills. Sialkot worker today has cross functional skills to switch over from making of sports goods to sportswear and leather garments.

\section{Gujrat Wooden Furniture Cluster}

Estimated annual sales of furniture from Gujrat is at around $\$ 50$ million with a growth rate of 10 percent per annum. Gujrat cluster is comprised of around 350 units, providing direct employment to more than 8,000 persons (SMEDA, 2006). These units are vertically integrated and are involved in the different stages of processes of furniture manufacturing. The furniture making units sell their products in both semi finished and finished form. Bulk of the production is for domestic consumption but a few units are also involved in exports to individual clients in UK, US, Saudi Arabia and the Middle East. The total export of furniture from Gujrat is valued at $\$ 4.5$ million. There is no specialized training institute for furniture making in Gujrat, except for a small wood working service center. It is the inherited skills which predominate. 


\section{Faisalabad Light Engineering Cluster}

Faisalabad cluster is demand driven to meet the needs of textile ginning mills, agricultural machines and other industry in the area. General purpose machines, industrial machines for textiles, parts of power looms, knitting machines, winder machines, warping machine, sizing machine, inter locking, jiggers, wheat threshers, choppers, plough blades etc are all made in this cluster. Foundries at Faisalabad supplement light engineering related setups of this sector. Complete textile machinery plants are not produced because of lack of knowledge and obsolete facilities to make precision parts. Low-tech machinery (e.g. auto looms, towel machinery \& wheat threshers) are being exported to several countries like Bangladesh, Sri Lanka and some of the African countries. Suffering from technological drawbacks, this sector has not been able to generate enough demand for full capacity utilization.

\section{Leather Tannery Clusters}

This industry thrives in many aspects as truly indigenous SME industry. This industry is second only to cotton textiles and its contribution to overall and regional economy can be highlighted in many aspects. The leather sector contributes around 5\% to GDP and 7\% to the total exports of the country (SMEDA, 2003). All together over 2500 tanneries are scattered in Pakistan. The industry offers direct employment to over quarter of a million.. The share of Pakistan in the global leather market is around \$ 0.6 billion (3\%) out of a total $\$ 20$ billion and this is met largely from over 725 small and medium size tanneries in clusters at Korangi (Karachi), Lahore, Multan, Kasur(Lahore), Faisalabad, Peshawar, Gujranwala, and Sialkot (SMEDA 2003 ). The leather tanning industry produces about 6 million hides and 36 million skins annually (Ghani, 2006) from cattle bred locally.. However, there have not been many changes in industry practices over decades.

\section{Information and Communication Technology Clusters}

Information Technology is one of the fastest growing sectors in Pakistan economy in terms of its revenue and size. Pakistan's total IT export revenue is estimated at $\$ 100$ million. Metropolitan cities of Lahore and Karachi are the two important clusters. Islamabad is another fast developing cluster in areas of call centers and BPOs.

\section{Sargodha Electrical Fittings Cluster}

Sargodha, Karachi and Lahore are major industrial areas for electrical fittings.. Almost 70\% of Pakistan's electrical fitting products are being produced in Sargodha. Over 1200 SMEs units employing around 100,000 persons operate in this sector (UNIDO/SMEDA, 2006). An estimated 10 million units/pieces of various electrical products like switches, sockets, power plugs, bells, TV \& telephone socket, holders, fan 
dimmers, ceiling roses etc. are produced monthly. Sargodha cluster currently suffers from a variety of technological obsolescence issues and structural \& institutional weaknesses. Industry is still working on conventional lines and does not use machines as wire cut, $\mathrm{CNC}$ milling and pantographs etc. for die/mold making. As such there is limited innovation and introduction of a few new product designs.

\section{Clusters related to Plastics goods}

The origin of plastics industry in Pakistan is traced to early days of creation of Pakistan. It was initiated and progressed in a haphazard manner producing low quality toys and household articles as mugs, plates, cups, and bowls on manually hand molding fly presses. Apparently, Lahore the all important commercial centre fitted as the most suitable location. The period 1965-1975 was notably the turning point, when the use of plastics rose in the country. Presently, $60 \%$ of the plastic industry is located in and around Lahore region forming a cluster of 700-800 units. Bottles and container manufacturers account for 50-60 units in this cluster. Other small clusters exist in urban areas of Karachi, Hattar, Gadoon, Faisalabad, Multan and Quetta.

\section{Clusters related to PVC Pipes and Related Products}

Plastic/PVC pipes are mainly used for water supply, drainage, conduits and ventilation.. It has $95 \%$ penetration in the conduit sector, $65 \%$ in tube well sector and $15 \%$ and $20 \%$ in drainage and water supply sector. The industry has around 400 manufacturing units, mainly SMEs. The installed capacity and the production are estimated at 75,000 metric tons and 45,000 metric tons per year. Two clusters, one each at Lahore (250 units) and Gujrat (25 units) stand out. PVC pipes industry has an obsolete technology base having 75 percent units equipped with locally made single screwextrusion machines. Rests of the 25 percent units are using twin-screw type refurbished old machinery of 80 's vintage, discarded by West European manufacturers. This sector has a desperate need to bring in latest technology, improve quality and seek new applications of the products.

\section{SME Clusters: Sri Lankan Experience}

The formation of clusters as a strategy to develop SMEs started in 2001 under the Competitiveness Program funded by the United States Agency for International Development (USAID) under a grant agreement with the Government of Sri Lanka. Under this project an industry cluster consists of members from every part of the business process - from raw material producers to manufactures to traders to retailers dealing directly with consumers. So constituted, the cluster serves as a proxy for value chain of an entire industry rather only the manufacturing part. Working together, members of the cluster learn to appreciate each other's perspectives and needs and arrive at a consensus on strategy and possibilities for more networking- what must be done to drive SMEs 
forward. Since 2001 eight industries have stepped forward with commitments to work intensively on issues related to their industry and to create ability to compete in the global market. These eight cluster areas are: Ceramics, Coir, ICT, Jewellery, Tea, Rubber,Spices and Tourism.

\section{Ceramics Cluster}

The Ceramics industry in Sri Lanka is composed of three major segments: tableware, (porcelain, stoneware or earthenware); ornamental artware (such as figurines, statuary, and decorations); and ceramic tile (wall tile and floor tile). There are at present approximately 30 ceramic companies in operation, seven of which are large, remaining being SMEs (Dasanayaka and Sardana, 2008). Total industry employment currently stands at approximately 20,000. On the supply side, Sri Lanka does not have large oil and natural gas deposits. It has to import LP gas. Energy costs are therefore relatively high. Certain key raw materials, such as china or ball clays, need to be imported to get the whiteness of porcelain. Overall, the Ceramic industry has reached a stage of stagnation. Ceramic exports have not grown for the last 10 years and the number of people employed in the industry directly and indirectly has remained static. Ceramics is part of fashion industry, where perception creates demand. The industry does not truly understand its ultimate consumer because it has been largely acting as "contract manufacturers". Lack of brand has created limitations in profitability. The industry has been largely lacking in R \& D and technical support. The Industrial Technology Institute (ITI) Center of Excellence together with implementation of joint research programs between the Ceramic Research and Development Centre and University of Moratuwa, are some of the tangible steps being taken by the industry cluster to address the problems.

\section{Coir Cluster}

Sri Lanka is the single largest supplier of coir fiber to the world market and together with India accounts for almost $90 \%$ of global coir exports. There are essentially four main categories of fiber grades ("Bristle", "Omat", "Mixed" and "Mattress"), which are either sold as raw material or processed into value added products such as brooms, brushes, scrapers, and twine, matting, woven and stitched geo-textiles; rubberized coir mattresses, and upholstery. Although Sri Lanka has traditionally been the lead exporter of coir fiber and pith, India holds the dominant position in terms of revenue generated by the industry, given the higher value-added component of its coir exports. Sri Lanka coir industry has also recently seized several competitiveness enhancing opportunities such as moving into coir-based erosion control products (geo-textiles) and high-end twine used in horticulture in North America and Japan. Yet, the industry continues to be threatened by synthetics, stagnating world coir prices and the poor and declining profitability of small mills, which form the basis of the industry. The industry provides part-time employment to an estimated 40,000 persons. At the start of the value chain are approximately 300 fiber millers and an estimated 500 suppliers of coir pith, or dust. The key strategic initiatives needed by the coir cluster are to manage product quality and improving productivity. 


\section{Information, Communication and Technology Cluster}

The Sri Lankan software industry even though still small has grown quite impressively. Exports, which stood at around $\$ 5.0$ million in 1996, increased to approximately $\$ 58.0$ in 2001 and reached $\$ 180.0$ million at the end of 2006. The software industry believes that Sri Lanka can achieve US\$ 1.0 billion in total ICT related export services by 2012. The ICT Industry Cluster, which has now been formally incorporated as the Sri Lanka ICT Association (SLICTA) is committed to transforming Sri Lanka into a sustainable, world-class center for high-value, rapidly evolving IT services. There are currently over 175 software development companies in Sri Lanka actively involved in the development of software products and provision of services to both the export and domestic markets. Some of the Sri Lankan firms that have made a mark in the international arena are; Millennium Information Technologies, Virtusa Corporation, and Informatics. In addition to that many foreign IT companies are operating in Sri Lanka. The Lanka Software Foundation (LSF), a non-profit organization has been formed to help Sri Lanka exploit the opportunities presented by the open-source world. Sri Lanka's strategy is not to compete on price but on quality and value addition.

\section{Jewellery Cluster}

An age-old industry in Sri Lanka, the gem and jewelry industry remains one of the country's largest net foreign exchange earners. The industry's potential for value addition, profitability and employment generation is high but remains untapped to a large extent. Sri Lanka is believed to possess one of the world's largest gemstone repositories, with concentrations of gem mining located in the Central and Southwest regions of the island. However, frequent re-mining together unproductive mining methods have been threatening this resource base for some time. Sri Lanka Gem \& Jewelry industry value chain is comprised of miners, heat-treaters, diamond cutters, lapidarists, jewelry manufacturers, brokers and retailers all of whom largely demonstrate insular behavior and function fairly independently of each other. Value adding activities, such as product certification and branding, have primary been taking place overseas, therefore the financial gains are enjoyed by third parties outside the country. The Sri Lanka Gem and Jewellery Association (SLGJA), was formed through the merger of four trade associations and is now recognized as the main private sector driven apex body. The Gem \& Jewelry Cluster, formed through the Competitiveness Program (TCP) now merged with SLGJA, now works as a permanent sub-committee on several strategic initiatives. The SLGJA has over 360 members from around the island. An important item on its agenda is to carry out National Gem Deposit Survey to establish locations, quality and extent of gem deposits and provide the basis for sustainable mining of the resource. Gem Stone Laboratory has been established for certification of gemstones. Gem \& Jewellery Institute has been established as a non-profit, private limited company to provide high-end training and services. 


\section{Rubber Industry Cluster}

The Sri Lanka rubber industry consists of the plantation sector, which grows and harvests latex from trees and converts this latex to processed raw rubbers of different types; and the rubber products manufacturing sector, which converts raw rubber into value added rubber goods. A third sector is emerging- the use of rubber wood as a material resource for manufacturing a wide range of wood based value added products. The plantation sector remains an important component as it is the 'resource base' or the primary competitive advantage of Sri Lanka's rubber industry. Sri Lanka recorded around 229,000 hectares under rubber plantation in the 1960s but currently the land area under rubber is less than 129,000 hectares. Of this area, approximately $65 \%$ is less than 20 hectares in size and mostly owned by smallholders. Sri Lanka rubber industry has four trade associations that promote private sector interests. The Plastics and Rubber Institute of Sri Lanka (PRI) is the main powerful lobby related to this industry and it conducts regular diploma courses in rubber and plastics technology. The remaining three include, the Colombo Rubber Traders Association, (CRTA), the Planters' Association of Ceylon (PA), and the Sri Lanka Association of Manufacturers and Exporters of Rubber Products (SLAMERP). The Sri Lanka Society of Rubber Industry (SRI), as the private sector driven apex body has objectives of development of the Rubber Cluster, formed with funded program- The Competitiveness Initiative. Its membership is comprised of the four main trade bodies: PRI, SLAMERP, CRTA and PA. The Sri Lanka's rubber cluster currently focuses on the following two strategic initiatives: consolidation of supply side/expansion of rubber plantations - 40,000 hectares in the Moneragala District, and Improving Marketing Effectiveness- "Lankaprene" Latex Crepe repositioning program.

\section{The Spices Cluster}

The growing and processing of spices provides cash income to large rural population. The main spice crops include cinnamon, pepper, cloves, cardamoms, nutmeg and mace. True cinnamon accounts for over 50\% of total spice exports. In 2003, the value of Sri Lankan spice exports was equivalent to 1 percent of total national exports, 7.6 percent of agricultural exports, and 50 percent of agricultural exports other than tea, coconuts, and rubber. Smallholders play an important role in the spice value chain where $70 \%$ of production comes from smallholder units of less than one hectare of land. There are approximately 400,000 small holder farm units in the country. The highest concentration of pepper and clove cultivation is found in the central hills while cinnamon is grown predominantly in the Southern Province. The Sri Lanka Spice Cluster was formed in 2001 with the assistance of the USAID funded program- The Competitiveness Initiative. The Cluster was formed in response to challenges, both global and local, facing the spice industry in Sri Lanka. Participants include growers, traders, distillers and extractors, exporters, brokers, associations, industrial technology institutes. In 2003 the Spice Cluster formalized itself by incorporating The Spice Council (TSC). 


\section{Tea Industry Cluster}

Sri Lanka is a world leader in tea exports and is especially strong in the market for traditional teas in the Middle East and CIS. In 2003, tea accounted 13 percent of Sri Lanka's merchandise exports and earned US \$683 million. The tea industry directly and indirectly employs 1 million people in Sri Lanka. Currently 8\% of Sri Lanka's tea export value is in the form of tea bags or instant tea products. Sri Lanka is the world's largest tea exporter with a 21 percent global export market share. Sri Lanka competes mainly in the orthodox tea market where it has a $32 \%$ market share and is the leading producer. However, $59 \%$ of tea exports are still in bulk form, the value of Sri Lanka's tea exports is still subject to commodity-based price swings. The small holder sector, which accounts for roughly $40 \%$ share of land under tea cultivation, continues to be more productive than the more traditional plantation sector and produces approximately $60 \%$ of tea grown in the country.

International tea marketers have historically positioned Sri Lanka, like other tea producing countries, as a supplier of bulk teas to the world. In the global tea trade, multinational companies tend to dominate in taking the product from producer to consumer. Therefore the Sri Lankan tea industry has an underdeveloped capacity to monitor consumer trends and add value to its product locally. Overall, the industry has been slow to innovate, upgrade, add value, and move closer to consumers with only a few notable exceptions of Sri Lankan-owned brands capturing and sustaining substantial market share overseas. The challenge for Sri Lanka's tea industry is to minimize the impact of price swings on its profit margins by differentiating and adding value to the product locally so as to command more stable world market pricing. The Tea Cluster was originally formed in May 2000 with the assistance of The Competitiveness Initiative to create a unified and holistic approach towards enhancing industry competitiveness. The Tea Cluster is currently implementing its competitiveness strategy through initiatives as Promotion, Brand ownership and Strategic alliances, increasing capacity for research, market intelligence and new product development, technology upgrading, and supply chain integration.

\section{Tourism Cluster}

In Sri Lanka, the tourism industry is a mainstay of the nation's economy, its fourth largest source of foreign exchange, and a major employer. However, over the last two decades, international tourist arrivals and tourism receipts in Sri Lanka have been weakening because of the continuing civil conflict and Tsunami devastation. In the past a packaged beach holiday product attracted a low-cost, low-value market segment. Current industry strategy is however focusing on value addition by catering to niche markets and offering specialized products such as Ecotourism, MICE (Meetings, Incentive Travel, Conventions and Exhibitions), Adventure tourism and Ayurveda/Spa tourism. Substantial investment has also been made in recent years on boutique resort hotels 
catering to more up-market clientele. The Tourism Cluster was formed by key tourism industry associations in 2000 under The Competitiveness Initiative (TCI). The Cluster was initiated to devise a unified, industry-wide strategy to enhance the competitiveness of the Sri Lanka tourism industry. A broad range of industry stakeholders participated in the Cluster's strategy work, including the Sri Lanka Tourist Board, Universities, Academic experts, community groups, regional tourism associations, and others. Some new initiatives such as Middle East and Asian emerging middle class focus are also underway. Ecolodge initiative is to establish a demonstration model for best practice ecotourism and establish standards for ecolodges in Sri Lanka. Save Energy initiatives aim to promote and encourage energy efficiency in the Sri Lankan hotel sector.

\section{Key Conclusions}

The comparative study throws up interesting but significant conclusions. Foremost, successful clusters enjoy locational advantages. An urban area is the most preferred site. For an SME entrepreneur, it provides safety of his home, urban amenities, facilities of schooling to his children, easy transport, efficient information and communication. Urban locations have strong economic dimensions as well. Such locations provide easy access to markets, strong infrastructure, access to producer services, and the ability to hire and retain knowledge workers. Urban areas are not necessarily the metropolitan areas with large population. Yusuf (2008) explains that these are also the cities which have acquired strong economic momentum by combining economic legacies and resource endowment with good policies. Furthermore, the new successful clusters are emerging near the core cities, as the core cities do not offer space for expansion or start of new units. Secondly, growth and long term survival of an SME is essentially related to its ability to innovate. It is not within the capability of the small scale to organize an independent R\&D. Perforce it has to depend on research institutions or other knowledge bodies. It is here that the role of the government and public bodies plays an important role. SME clusters survive if there is a nearby provision of Universities, research institutions, technical schools. IT sector in Sri Lanka has grown for a simple reason that it is supported by engineers graduating every year from Sri Lanka's Technical and Engineering Colleges. Pakistan has lacked in this direction even in such areas, as Leather products, Textiles where it enjoyed superiority of available raw materials, but could not provide latest technology and innovation to its SMEs clusters.

Thirdly, there is only a limited success of SME clusters which can be traced to fiscal subsidies, land benefits as offered by the local bodies/regional government/central government to set up the cluster in remote specified under-developed areas. Only such of the clusters have reported success which came up in remote areas because of anchoring support provided by large undertakings. A cluster in an urban area location outweighs all such types of benefits. 
Fourthly, there is only an inadequate role played by the governments in both countries to promote the SME clusters. The political leadership in both countries has shown keenness to seek presence of large multinational or local large organizations through direct foreign investments or fiscal and monetary encouragements. Special Economic Zones (SEZ), as in case of Sri Lanka, have attracted large firms. The potential of the SMEs has remained unleashed. Lastly, both countries have a common malaise of non-availability of data on the working of the clusters. But however compared with Sri Lanka SMEs cluster and networking achievements, Pakistan is a well ahead of this concept. This is evidenced by such observations by global agencies as UNIDO and ILO in their studies..

\section{REFERENCES}

Basant, Rakesh (2008), Bangalore Clusters: Evolution, Growth and Challenges. In Yusuf, S., Kaoru Nabeshima, and Shoichi Yamashita (ed.), Growing Industrial Clusters in Asia. Washington. DC: The World Bank

Cook Philip (2002), Knowledge Economies: Clusters, Learning and cooperative advantage. In Yusuf, S., Kaoru Nabeshima, and Shoichi Yamashita (ed.), Growing Industrial Clusters in Asia. Washington. DC: The World Bank

Cortright, Joseph (2006), Making Sense of Clusters: Regional Competitiveness and Economic Development. In Yusuf, S., Kaoru Nabeshima, and Shoichi Yamashita (ed.), Growing Industrial Clusters in Asia. Washington. DC: The World Bank

Dasanayaka.S, and Sardana.G.D (2008), Organizational culture and Innovation: An Exploratory study of Sri Lanka Gift and Decorative-ware Sector Firms, Euro Asia Journal of Management, Issue 36, Vol.18, No. 2, December 2008, pp 103-122

Feldman, Maryann P., Johanna Francis (2005), Homegrown Solutions: Fostering Cluster Formation. In Yusuf, S., Kaoru Nabeshima, and Shoichi Yamashita (ed.), Growing Industrial Clusters in Asia. Washington. DC: The World Bank

Ghani.E (2006), 'The Pakistan's Leather Industry' in PIDE/HEC, Technology Based Industrial Vision and Strategy for Pakistan's Socio Economic Development, Govt. of Pakistan, Islamabad, Pakistan

Glavan,B. (2007), Coordination Failures, Cluster Theory and Entrepreneurship: A Critical View, MPRA Paper, No: 6275, Posted 13

Harrison, John. (2007), From Competetive Regions to Competetive City-Regions: A New Orthodoxy, but some old mistakes. In Yusuf, S., Kaoru Nabeshima, and Shoichi 
Yamashita (ed.), Growing Industrial Clusters in Asia. Washington. DC: The World Bank

Kuah Adrian T.H. Cluster Theory and the Small Business: 206 - 228 C Journal of Research in Marketing and Entrepreneurship: Volume Four, Issue 3, 2002.

Markusen, Ann R. (1994), Sticky Places in Slippery Space" The Political Economy of Postwar Fast-Growth Regions. In Yusuf, S., Kaoru Nabeshima, and Shoichi Yamashita (ed.), Growing Industrial Clusters in Asia. Washington. DC: The World Bank

Marshall Alfred (1890), Principles of Economics: An Introductory Volume, Rod Hay's archive for the History of Economic Thought, Mc Master University, Canada

Porter.M.E., (1990), The Competitive Advantages of Nations, Harvard Business Review, March-April, No.02, pp 73-90.

Sarcina, Ruggiera (2009), Organizational Learning" the role of SME clusters, http://www.pjb.co.uk/npl/bp19.htm, Accessed on $6^{\text {th }}$ January, 2009.

SMEDA (2003), "Pakistan Investment Guide". Experts Advisory Cell, Leather Sector of Pakistan, Ministry of Industries \& Production, Islamabad. (www.smeda.org.pk).

SMEDA( 2006), SME Policy 2006: Small and Medium Enterprise Development Authority., Ministry of Industries \& Production, Islamabad. (www.smeda.org.pk).

Swann, G.M.P.; Baptista, R. (1998), “Do Firms in Cluster Innovate More?”, Research Policy, Vol. 27 (5), pp 527-542

UNIDO (2003), Methodology and the Action Plan for Updation of Data on SME Industrial Clusters. http://web5.laghuudyog.com/clusters/unido/methcludata.htm, accessed on $6^{\text {th }}$ January, 2009.

Yusuf, Shahid (2008), Can Clusters Be Made to Order. In Yusuf, S., Kaoru Nabeshima, and Shoichi Yamashita (ed.), Growing Industrial Clusters in Asia. Washington. DC: The World Bank.

\section{The Price of Success}

The upward mobility of the knowledge society, however, comes at a high price: the psychological pressures and emotional traumas of the rat race. There can be winners only if there are losers. This was not true of earlier societies. The son of the landless laborer who became a landless laborer himself was not a failure. In the knowledge society, however, he is not only a personal failure but a failure of society as well.

P.F. Drucker: Managing in the Next Society, pp. 262 